\title{
Intestinal Parasites in Ecotourism Region of the State of Paraná, Brazil
}

\author{
Dina Lúcia Morais Falavigna ${ }^{1 *}$, Amanda Andrea de Almeida ${ }^{2}$, Renata Sayuri Iwazaki ${ }^{2}$ and \\ Silvana Marques de Araújo ${ }^{1}$ \\ ${ }^{1}$ Laboratório de Parasitologia Básica; Departamento de Análises Clínicas; Universidade Estadual de Maringá; Av. \\ Colombo, 5790; Bloco I-90, sala 11; dlmfalavigna@uem.br; 87020-900; Maringá - PR - Brasil. ${ }^{2}$ Universidade \\ Paranaense; Umuarama - PR - Brasil
}

\begin{abstract}
To determine the indices of prevalence of intestinal parasites and commensals in the residents of ecotourism region of Paraná State, a retrospective study was conducte, from January/2003 to December/2004 on 3,764 fecal parasitological examinations performed by a private laboratory of Ubiratã using the Baermann-Moraes, watersedimentation and Willis methods. Among the individuals aged eight months to 89 years, 522 (13.9\%) cases were positive. Giardia lamblia $(175 / 522 ; 24.2 \%)$ was the most prevalent parasite ( $p<0.000)$. Entamoeba coli was the most common commensal, with 238/552 (32.9\%) cases ( $p<0.000)$, being frequently associated with other species, either parasitic or commensal. The children of preschool age (2-6 years old) and school age (7-14 years) were mainly parasitized (66.0\% of positivity; $p<0.0000)$. More individuals harbored a single species of parasite (233; 44.6\%) than had multiple species (169; 32.4\%). These results indicated a significant degree of the environmental contamination in the cities of Paraná, mainly the medium-and small-sized ones, which was a cause for concern in view of the increase in ecotourism in the region.
\end{abstract}

Key words: Intestinal Parasites, Ecotourism, Travelers Parasitology, Paraná

\section{INTRODUCTION}

The world is a complex ecosystem in which human disease patterns vary from one country to another (Jekel et al., 1999). The presence of different species of the intestinal parasites and the rates of the intestinal parasitism can be viewed as a digital impression, because it is intimately correlated with the climate and economic factors such as per capita income, lifestyle and occupation (Tashima and Simões, 2004). Still a serious public health problem, mainly in the developing countries, intestinal parasitoses are cosmopolitan especially in the tropical regions (Crompton and Savioli, 1993). In spite of the urbanization in Latin America over the last four decades, which led to decreased percentages of intestinal parasitic infections, the absolute number of the cases of the intestinal parasitoses in both urban and rural regions has increased (Cancrini et al., 1989; CostaMacedo and Rey, 2000). Associated with a framework of the chronic diarrhea and malnutrition, the intestinal parasitoses often compromise the physical and intellectual development, especially among the youngest age groups in a population (Ludwig et al., 1999).

*Author for correspondence 
The population studies of the intestinal parasites in different regions of Brazil reveal frequencies that differ greatly according to the local sanitation conditions and the characteristics of the sample analyzed (Tavares-Dias and Grandini, 1999; Rocha et al., 2000; Giraldi et al., 2001; Amato Neto et al., 2004). However, in a country where intestinal parasitoses figure among the main public-health problems, the parasitological investigation has been widely neglected (Ferreira and Marçal Jr., 1997).

In Paraná, thorough investigations of the fecal parasites have focused mainly on the school-age children residing in the larger cities such as Curitiba, Londrina, Maringá and Cascavel (Ogliari and Passos, 2002; Márquez et al., 2002; Ferreira et al., 2004; Pupulim et al., 2004). Little is known about the prevalence of the intestinal parasites and commensals in the medium-sized and small cities in the state. In order to broaden the knowledge of the health conditions in Paraná, and in particular because the city of Ubiratã is located on the ecotourism route in this state, this study was conducted to determine the indices of the prevalence of intestinal parasites and commensals in the residents of Ubiratã, Paraná.

\section{MATERIAL AND METHODS}

The Municipality of Ubiratã is located in the Central-Western meso-region of Paraná and in the Goioerê micro-region, $535 \mathrm{~km}$ from Curitiba (Secretaria Estadual de Desenvolvimento Urbano do Estado do Paraná - SEDU/PR). Located at latitude $24^{\circ} 32^{\prime} 10^{\prime \prime} \mathrm{S}$ and longitude $52^{\circ} 58^{\prime} 50^{\prime \prime} \mathrm{W}$, the city has an altitude of $550 \mathrm{~m}$. The climate is mesothermal humid subtropical, with hot summers when the rainfall tends to be higher (mean temperature above $22^{\circ} \mathrm{C}$ ), and winters with infrequent frosts (mean temperature below $18^{\circ} \mathrm{C}$ ); there is no defined dry season (Secretaria Estadual de Desenvolvimento Urbano do Estado do Paraná - SEDU/PR). Ubiratã has 22,593 inhabitants, 17,240 of whom reside in the urban zone and 5,353 in the rural zone (IBGE. Cidades@). Agriculture is the main socio-economic activity in the municipality. The city of Ubiratã is a route of the people who consider the ecotourism or radical sports as a tandem flight or rafting about the risk of parasite infections, as the region has beautiful waterfalls, streams and hills.
This study analyzed all the results of fecal examinations performed by a private laboratory in Ubiratã over the period January 2003 through December 2004. The examinations, all of which had been requested by the doctors, were performed by the Baermann-Moraes, Hoffman and Willis methods (De Carli, 2001).

The data were analyzed by the program Statistica (version 6.0). The observed differences in the annual and overall prevalences and the distribution of the cases by the sex and age group were tested by the Chi-square test at a significance level of $5.0 \%$.

\section{RESULTS}

Over the two years, 3,764 fecal examinations were done: 2,690 were subsidized through the Federal Health Care System (Sistema Único de Saúde SUS) (71.5\%), and 1,074 were paid for privately or through health plans $(28.5 \%)$. A total of 522 $(13.9 \%)$ examinations revealed at least one species of the protozoan or helminth. The prevalence of parasites and commensals is shown in Table 1.

There was no difference between the percentage of the positive fecal examinations in $2004(13.8 \%)$ compared to $2003(13.9 \%)$ ( $\mathrm{p}=0.9368)$. $G$. intestinalis was most common parasite with 175 $(24.2 \%)$ parasited persons $(\mathrm{p}<0.000)$ and $E$. coli predominated among the commensals with 238 $(32.9 \%)$ positive cases $(\mathrm{p}<0.000)$. The ages of the individuals ranged from eight months to 89 years, with a median of 10 years. There was no difference between the general prevalence of the parasites among the age groups analyzed $(\mathrm{p}=$ 0.8843 ). The children of pre-school (2 to 6 years) and school age (7 to 14 years) were most affected ( $p<0.0000$ ), constituting $66.0 \%$ of the positive fecal examinations (Table 1). The incidence of the infection in the children aged 7 to 14 was 1.3 times higher than in the children aged 2 to 6 , and 6.2 times higher than the other age groups. The most frequent parasite in the 0-14 age group was $G$. intestinalis (27.8\%), followed by Ascaris lumbricoides and Enterobius vermicularis. In the 21 to 30-year age group, Ancylostomatidae were the most prevalent parasites (Table 1). There was no significant difference in the percentages of the positivity for the parasitized females $(18.9 \%)$ and males $(19.4 \%)(\mathrm{p}=0.8341)$ (Table 2). 
Table 1 - Distribution of intestinal commensals and parasites by age group, in residents of Ubiratã, Paraná, from January 2003 through December 2004.

\begin{tabular}{|c|c|c|c|c|c|c|c|c|c|c|c|c|c|c|c|c|c|c|}
\hline \multirow{3}{*}{$\begin{array}{l}\text { Commensals } \\
\text { and parasites }\end{array}$} & \multicolumn{16}{|c|}{ Age group (years) } & \multirow{2}{*}{\multicolumn{2}{|c|}{ Total }} \\
\hline & \multicolumn{2}{|c|}{$0-1$} & \multicolumn{2}{|c|}{$2-6$} & \multicolumn{2}{|c|}{$7-14$} & \multicolumn{2}{|c|}{$15-20$} & \multicolumn{2}{|c|}{$21-30$} & \multicolumn{2}{|c|}{$31-40$} & \multicolumn{2}{|c|}{$41-50$} & \multicolumn{2}{|c|}{$>\mathbf{5 0}$} & & \\
\hline & $\mathrm{n}$ & $(\%)$ & $\mathrm{n}$ & $(\%)$ & $\mathrm{n}$ & $(\%)$ & $\mathrm{n}$ & $(\%)$ & $\mathrm{n}$ & $(\%)$ & $\mathrm{n}$ & $(\%)$ & $\mathrm{n}$ & $(\%)$ & $\mathrm{n}$ & $(\%)$ & $\mathrm{n}$ & $(\%)$ \\
\hline Endolimax nana & 0 & $(0.0)$ & 2 & $(0.2)$ & 3 & $(0.2)$ & 1 & $(0.3)$ & 2 & $(0.7)$ & 1 & $(0.6)$ & 1 & $(0.6)$ & 0 & $(0.0)$ & 10 & $(0.3)$ \\
\hline E. coli & 3 & $(2.1)$ & 43 & $(4.1)$ & 102 & $(7.5)$ & 23 & $(6.6)$ & 20 & $(6.6)$ & 17 & $(9.4)$ & 15 & $(8.5)$ & 15 & $(7.4)$ & 238 & $(6.3)$ \\
\hline $\begin{array}{l}\text { Iodamoeba } \\
\text { butschlii }\end{array}$ & 0 & $(0.0)$ & 1 & $(0.1)$ & 2 & $(0.1)$ & 0 & $(0.0)$ & 0 & $(0.0)$ & 1 & $(0.6)$ & 0 & $(0.0)$ & 0 & $(0.0)$ & 4 & $(0.1)$ \\
\hline $\begin{array}{l}\text { E. histolytica / E. } \\
\text { dispar }\end{array}$ & 0 & $(0.0)$ & 16 & (1.5) & 41 & $(3.0)$ & 10 & $(2.9)$ & 10 & $(3.3)$ & 3 & $(1.7)$ & 6 & $(3.4)$ & 6 & $(3.0)$ & 92 & (2.4) \\
\hline $\begin{array}{l}\text { Giardia } \\
\text { intestinalis }\end{array}$ & 20 & (14.3) & 78 & $(7.5)$ & 47 & (3.4) & 11 & $(3.1)$ & 8 & (2.7) & 4 & $(2.2)$ & 1 & $(0.6)$ & 6 & $(3.0)$ & 175 & (4.6) \\
\hline Ancylostomatidae & 0 & $(0.0)$ & 6 & $(0.6)$ & 8 & $(0.6)$ & 4 & $(1.1)$ & 9 & $(3.0)$ & 2 & $(1.1)$ & 4 & $(2.3)$ & 5 & $(2.5)$ & 38 & (1.0) \\
\hline $\begin{array}{l}\text { Ascaris } \\
\text { lumbricoides }\end{array}$ & 1 & $(0.7)$ & 23 & $(2.2)$ & 39 & (2.9) & 9 & (2.6) & 2 & $(0.7)$ & 0 & $(0.0)$ & 1 & $(0.6)$ & 3 & $(1.5)$ & 78 & (2.1) \\
\hline $\begin{array}{l}\text { Enterobius } \\
\text { vermicularis }\end{array}$ & 1 & $(0.7)$ & 5 & $(0.5)$ & 15 & $(1.1)$ & 4 & $(1.1)$ & 1 & $(0.3)$ & 2 & $(1.1)$ & 0 & $(0.0)$ & 0 & $(0.0)$ & 28 & $(0.7)$ \\
\hline Hymenolepis nana & 2 & $(1.4)$ & 1 & $(0.1)$ & 11 & $(0.8)$ & 1 & $(0.3)$ & 0 & $(0.0)$ & 0 & $(0.0)$ & 0 & $(0.0)$ & 0 & $(0.0)$ & 15 & $(0.4)$ \\
\hline $\begin{array}{l}\text { Strongyloides } \\
\text { stercoralis }\end{array}$ & 0 & $(0.0)$ & 3 & $(0.3)$ & 10 & $(0.7)$ & 2 & $(0.6)$ & 6 & $(2.0)$ & 3 & (1.7) & 6 & $(3.4)$ & 4 & $(2.0)$ & 34 & $(0.9)$ \\
\hline $\begin{array}{l}\text { Trichuris } \\
\text { trichiura }\end{array}$ & 0 & $(0.0)$ & 3 & $(0.3)$ & 4 & $(0.3)$ & 2 & $(0.6)$ & 1 & $(0.3)$ & 0 & $(0.0)$ & 0 & $(0.0)$ & 0 & $(0.0)$ & 10 & $(0.3)$ \\
\hline Total examined & 140 & (19.3) & 1046 & (17.3) & 1366 & (20.6) & 350 & (19.1) & 301 & (19.6) & 181 & (18.2) & 177 & $(19.2)$ & 203 & $(19.2)$ & 3.764 & $(13.9)^{*}$ \\
\hline
\end{tabular}

Table 2 - Distribution of intestinal commensals and parasites in male and female residents of Ubiratã, Paraná, from January 2003 through December 2004.

\begin{tabular}{|c|c|c|c|c|c|c|}
\hline \multirow[t]{3}{*}{ Commensals and parasites } & \multicolumn{4}{|c|}{ Sex } & \multicolumn{2}{|c|}{ Total } \\
\hline & \multicolumn{2}{|c|}{ Male } & \multicolumn{2}{|c|}{ Female } & \multirow[b]{2}{*}{$\mathbf{n}$} & \multirow[b]{2}{*}{$(\%)$} \\
\hline & $\mathbf{n}$ & $(\%)$ & $\mathbf{n}$ & $(\%)$ & & \\
\hline Endolimax nana & 5 & $(0.3)$ & 5 & $(0.3)$ & 10 & $(0.3)$ \\
\hline Entamoeba coli & 129 & $(7.0)$ & 109 & $(5.7)$ & 238 & $(6.3)$ \\
\hline Iodamoeba butschlii & 0 & $(0.0)$ & 4 & $(0.2)$ & 4 & $(0.1)$ \\
\hline E. histolytica / E. dispar & 49 & $(2.7)$ & 43 & $(2.2)$ & 92 & $(2.4)$ \\
\hline Giardia intestinalis & 72 & $(3.9)$ & 103 & $(5.4)$ & 175 & $(4.6)$ \\
\hline Ancylostomatidae & 18 & $(1.0)$ & 20 & $(1.0)$ & 38 & $(1.0)$ \\
\hline Ascaris lumbricoides & 33 & $(1.8)$ & 45 & $(2.3)$ & 78 & $(2.1)$ \\
\hline Enterobius vermicularis & 15 & $(0.8)$ & 13 & $(0.7)$ & 28 & $(0.7)$ \\
\hline Hymenolepis nana & 6 & $(0.3)$ & 9 & $(0.5$ & 15 & $(0.4)$ \\
\hline Strongyloides stercoralis & 18 & $(1.0)$ & 16 & $(0.8$ & 34 & $(0.9)$ \\
\hline Trichuris trichiura & 4 & $(0.2)$ & 6 & $(0.3)$ & 10 & $(0.3)$ \\
\hline Total patients examined & 1846 & (18.9) & 1918 & (19.44) & 3764 & (13.9) \\
\hline
\end{tabular}


More individuals harbored only a single parasite species $(233 ; 44.6 \%)$ than the multiple parasite species $(169 ; 32.4 \%)$. E. coli was the species most frequently associated with other species, parasitic or commensal (Tables 3). In 69 examinations, which comprised $13.2 \%$ of the positive cases, E.coli occurred together with Entamoeba histolytica/Entamoeba dispar. Ascaris lumbricoides was the intestinal parasite associated with the highest number (ten) of different species. Two species were associated in $140(26.8 \%)$ cases, and three or more species in $29(5.6 \%)$ cases (Table 3). The association between the parasites and commensals was significantly $(\mathrm{p}<0.0000)$ higher among the parasites (Tables 3).

\section{DISCUSSION}

This investigation utilized the results of 3,760 fecal examinations. Considering the calculation of the sample based on the population of the municipality determined by the program EPIINFO 2002 - version 6.0, with an expected frequency of 23\% (Porcu and Watanabe, 1998), an acceptable $17 \%$ error and $99.99 \%$ confidence level, 1,560 examinations were required to accurately estimate the prevalence of the parasites in Ubiratã. Therefore, the present results were considered consistent. The large number of the examinations carried out in two years was equivalent to analyzing $16.7 \%$ of the population of the municipality of Ubiratã.

Table 3 - Single and multiple-species parasitism in residents of Ubiratã, Paraná, from January 2003 through December 2004.

\begin{tabular}{|c|c|}
\hline Single-species parasitism & $\mathbf{N}$ \\
\hline A. lumbricoides & 42 \\
\hline Ancylostomatidae & 17 \\
\hline E. histolytica/E. dispar & 1 \\
\hline E. vermicularis & 18 \\
\hline G. intestinalis & 129 \\
\hline H. nana & 7 \\
\hline S. stercoralis & 15 \\
\hline T. trichiura & 4 \\
\hline Total & 233 \\
\hline Multiple-species parasitism & $\mathbf{N}$ \\
\hline A. lumbricoides + E. vermicularis & 1 \\
\hline A. lumbricoides $+G$. intestinalis & 12 \\
\hline A. lumbricoides $+H$. nana & 1 \\
\hline A. lumbricoides $+T$. trichiura & 1 \\
\hline Ancylostomatidae + A. lumbricoides & 1 \\
\hline Ancylostomatidae $+G$. intestinalis & 6 \\
\hline Ancylostomatidae + S. stercoralis & 8 \\
\hline Ancylostomatidae $+G$. intestinalis + S. stercoralis & 1 \\
\hline E. vermicularis + Ancylostomatidae & 1 \\
\hline E. vermicularis $+G$. intestinalis & 1 \\
\hline E. vermicularis $+S$. stercoralis & 1 \\
\hline E. vermicularis + T. trichiura & 1 \\
\hline H. nana $+G$. intestinalis & 1 \\
\hline S. stercoralis + A. lumbricoides & 2 \\
\hline S. stercoralis + A. lumbricoides + G. intestinalis & 1 \\
\hline S. stercoralis $+G$. intestinalis & 4 \\
\hline T. trichiura + Ancylostomatidae & 1 \\
\hline Total & 44 \\
\hline
\end{tabular}


In this municipality, where the per capita income was R\$382.00 per month, a high percentage of patients used SUS rather than health plans or individual payment for the examinations.

According to the IBGE, in 2000 in Paraná, only $20.9 \%$ (156) of the municipalities had sewage treatment systems. In Ubiratã, only 70 of the 6,276 households were connected to the sewage system, 5,207 residences had the running water, and 4,985 had trash collection (IBGE-cidades@). In 2002 and 2003, nine deaths caused by the infectious and parasitic diseases were recorded. In agreement with the Human Development Index (HDI) of 2000, Ubiratã ranked 228th among the municipalities in the state of Paraná and 2327th among the Brazilian cities; i.e., it was not included in the middle of the more prosperous cities in the country (IBGE-cidades@). It could be concluded that the environmental contamination in the cities of Paraná, primarily medium- and small cities, were high. Nevertheless, the prevalence of the intestinal parasites and commensals observed in Ubiratã was $13.9 \%$, lower than the levels found in the larger municipalities such as Maringá, where $23 \%$ of 4,939 fecal parasitological examinations were positive (Porcu and Watanabe, 1998). Apparently the data were underestimates in the present investigation, since the laboratory did not use the specific methodology for the protozoans and only one sample was collected per individual.

Giardia intestinalis, a protozoan frequently found in the children up to six years old, in proportions varying from $5.6 \%$ (Machado et al., 1999) to 78.3\% (Machado and Costa-Cruz, 1998), was the principal parasite found in the population studied. The prevalence of this parasite, together with the fecal-orally transmitted commensals such as Entamoeba coli, found in $32.9 \%$ of the population of Ubiratã, functioned as the bioindicators of the socio-environmental conditions, hygiene, basic sanitation and quality of the life of the population (Costa-Macedo et al., 1999; Faulkner et al., 2003). Person-to-person transmission of the giardiasis could also be an important factor, because in the closed communities such as the schools and daycare centers, or in the residences that were very close to each other, fecal-oral propagation of many intestinal parasites and commensals could be facilitated (Guilherme et al., 2004; Pupulim et al., 2004). Although the prevalence of G. intestinalis in Ubiratã were similar to the prevalence levels in other cities in Paraná (Márquez et al., 2002; Ferreira et al., 2004; Giraldi et al., 2004; Pupulin et al., 2004), this prevalence might be higher, because this protozoan, in addition to the reasons listed at the end of the previous paragraph, sheded cysts intermittently (Rocha et al., 2000).

The progressive increase in the prevalence of the intestinal parasites up to 14 years could be due to the behavioral changes in the process of the growth and child development that favored the mobility and interaction with the environment, increasing the exposure time to the environments lacking of adequate basic sanitation (CostaMacedo et al., 1998; Tashima and Simões, 2004). The decrease in prevalence rates at ages over 15 years coud be explained in part by the immunemediated resistance, acquired through the successive contacts with the parasite, and partly through more effective personal hygiene as the child grew (Rocha et al., 2000). According to Giraldi et al. (2001), contact with soil was one of the most important factors in transmission of the parasitoses to the children under six, whereas the contamination of the water and food was significant in ages over six.

The prevalence of the helminths A. lumbricoides and E. vermicularis in the preschool- and schoolaged children, at a rate of $5.4 \%$, was higher than reported by other investigators (Tavares-Dias and Grandini, 1999; Rocha et al., 2000; Giraldi et al., 2001; Tashima and Simões, 2004), although this study used no specific methodology for $E$. vermicularis. This finding indicated the existence of poor hygiene conditions in the environments where the individuals were crowded together in a population that could easily be reached by the education about sanitation, because it consisted mainly of the students.

The finding of infected children under the age of two raised the possibility that the hands, pacifiers and domestic animals were vehicles for acquiring the parasites, reflecting the degree of domiciliary and peridomestic contamination resulting from the unsatisfactory conditions of the basic sanitation (Costa-Macedo et al., 1999; Giovannoni and Kubiak, 2001). Investigating the means of transmission of protozoans and helminths on the pacifiers of children from 0 to 7 years old residing in the Alfenas neighborhood in Minas Gerais, Pedroso and Siqueira (1997) found that 10/86 $(11.6 \%)$ of the pacifiers were contaminated, mainly by $A$. lumbricoides and $E$. vermicularis.

The prevalence of multiple parasitism in the population investigated was high. The association between parasites and commensals occurred 
because of the imbalance in the intestinal flora and physiology caused by the presence of the parasites. This imbalance facilitated the intestinal colonization by the commensals such as Entamoeba coli. According to Foratini (2001) the establishment of the parasite communities presupposed a series of the metabolic and trophic advantages that increased the probability of the survival of the parasites.

According to UNICEF (1995), the prevalence of the intestinal parasites in the population under five years of age closely reflected the degree of environmental contamination of a region, because these individuals had less mobility and were more vulnerable. The data in the present work allied to the information mentioned above and the location of Ubiratã on the ecotourism route that according Lutterbach et al. (2001) facilitated the environmental contamination, highlighted the question of the adequacy of the health policy and intervention to limit the spread of the diseases related to the poor environmental sanitation.

\section{RESUMO}

A prevalência de enteroparasitas e comensais, de janeiro/2003 a dezembro/2004, foi determinada em residentes de região de ecoturismo do Paraná por meio de estudo retrospectivo. Foram examinados os resultados de 3.764 exames coproparasitológicos efetuados em laboratório privado de Ubiratã Entre indivíduos de 8 meses a 89 anos, $522(13,9 \%)$ exames foram positivos. Giardia intestinalis $(175 / 522 ; 24,2 \%)$ foi o parasita prevalente $(\mathrm{p}<0,000)$. Entamoeba coli mostrou-se o commensal mais comum, com $238 / 552(32,9 \%)$ casos $(p<0,000)$, encontrando-se frequentemente associado com outras espécies, parasitas ou comensais. Crianças em idade préescolar (2-6 anos) e escolar (7-14 anos) apresentaram-se mais parasitados $(66,0 \%$ de positividade; $\mathrm{p}<0,0000)$. A maioria dos indivíduos encontrava-se parasitado por uma única espécie $(233 ; 44.6 \%)$ do que por várias espécies (169; $32.4 \%$ ). Estes resultados indicam um grau significativo de contaminação ambiental em cidades do Paraná, principalmente aquelas de médio e pequeno porte, representando fonte de preocupação em vista do crescimento do ecoturismo na região.

\section{REFERENCES}

Amato Neto, V.; Alarcon, R. S. R.; Gakiya, E.; Ferreira, C. S.; Bezerra, R. C.; Santos, A. G. (2004), Elevada porcentagem de blastocistose em escolares de São Paulo, SP. Rev. Soc. Bras. Med. Trop., 37, 354-356.

Cancrini, G.; Bortoloni, A.; Paradisi, F.; Nunes, L. E. (1989), Parasitological observations on three Bolivian localities including rural communities, cities and institutions. Ann. Trop. Méd. Parasit., 83, 591-594.

Costa-Macedo, L. M.; Rey, L. (2000), Aleitamento e parasitismo intestinal materno-infantil. Rev. Soc. Brás. Méd. Trop., 33, 371-375.

Costa-Macedo, L. M.; Costa, M. C. E.; Almeida, L. M. (1999), Parasitismo por Ascaris lumbricoides em crianças menores de dois anos: estudo populacional em comunidade do Estado do Rio de Janeiro. Cadernos de Saúde Pública, 15, 173-178.

Costa-Macedo, L. M.; Machado-Silva, J. R.; RodriguesSilva, R.; Oliveira, L. M.; Vianna, M. S. R. (1998), Enteroparasitoses em pré- escolares de comunidades favelizadas da cidade do Rio de Janeiro. Caderno de Saúde Pública, 14, 851-855.

Crompton, D. W. T., Savioli L. (1993), Intestinal parasitic infections and urbanization. Bull. Pan. Am. Health Organ.,.71, 1-7.

De Carli, A. (2001), Parasitologia Clínica: seleção de métodos e técnicas de laboratório para o diagnóstico de parasitoses humanas. Editora Atheneu, São Paulo, $810 \mathrm{pp}$.

Faulkner, C. T.; Garcia, B. B.; Logan, M. H.; New, J. C.; Patton, S. (2003), Prevalence of endoparasitic infection in children and its relation with cholera prevention efforts in Mexico. Rev. Pan. Salud Pub., 14, 31-41.

Ferreira, C. B., Marçal Jr., O. (1997), Enteroparasitoses em escolares do distrito de Martinésia, Uberlândia, MG: um estudo-piloto. Rev. Soc. Bras. Med. Trop., 30, 373-377.

Ferreira, J. R.; Volpato, F., Carricondo, F. M.; Martinichen, J. C.; Lenartovicz, V. (2004), Diagnóstico e prevenção de parasitoses no reassentamento São Francisco em Cascavel - PR. Rev. Bras. Anal. Clín., 36, 145-146.

Foratini, O. P. (2001), O pensamento epidemiológico evolutivo sobre as infecções. Rev. Saúde Públ., 36, 257-262.

Giovannoni, Milton and Kubiak, Gastão V. L. (2001), Fauna Parasitológica Paranaense: IV. Lista Prévia da Ocorrência de Helmintos em Animais Domésticos. Braz. arch. biol. technol., vol. jubilee, 289-292. 
Giraldi, N.; Vidotto, O.; Navarro, I. T.; Garcia, J. L. (2001), Prevalência de enteroparasitoses em crianças de creches e alunos da rede municipal de ensino de Rolândia, Paraná. Rev. Soc. Bras. Méd. Trop., 34, 385-387.

Guilherme, A. L. F.; Falavigna, D. L. M.; Araujo, S. M.; Pupulim, A. R. T.; Lima Jr, J. E. (2004), Parasitas intestinais e comensais em indivíduos de três Vilas Rurais do Paraná, Brasil. Acta Scientiarum Health Science, 26, 331-336.

IBGE. Cidades @. - Instituto Brasieliro de Geografia E Estatística. http://www.ibge.gov.br/cidadesat/. Accessed on 15 May 2005.

Jekel, J. F.; Elmore, J. G.; Katz, D. L. (1999), Epidemiologia, bioestatística e medicina preventiva. Ed. Artes Médicas Sul, Porto Alegre, 328 pp.

Ludwig, K.M.; Frei, F.; Alvares Filho, F.; Ribeiro-Paes, J.T. (1999), Correlação entre condições de saneamento básico e parasitoses intestinais na população de Assis, Estado de São Paulo. Rev. Soc. Bras. Med. Trop., 32, 547-555.

Lutterbach M.T.S; Vazquez J.C.; Pinet J.A.; Andreata J.V.; Silva A.C. (2001), Monitoring and spatial distribution of heterotrophic bacteria and fecal coliforms in the Rodrigo de Freitas Lagoon, Rio de Janeiro, Brazil. Braz. arch. biol. technol. 44, 07-13.

Machado, E. R.; Costa-Cruz, J. M. (1998), Strongyloides stercoralis and other enteroparasites in children at Uberlândia City, State of Minas Gerais, Brazil. Mem. Inst. Oswaldo Cruz, 93, 161-164.

Machado, R. C.; Marcari, E. L.; Cristante, S. F. V.; Carareto, C. M. A. (1999), Giardíase e helmintíases em crianças de creches e escolas de $1^{\circ}$ e $2^{\circ}$ graus (públicas e privadas) da cidade de Mirassol (SP, Brasil). Rev. Soc. Bras. Med. Trop., 32, 697-704.

Márquez, A. S.; Márquez, A. S.; Hasenack, B. S.; Trapp, E. H.; Guilherme, R. L. (2002), Prevalência de enteroparasitoses em crianças de um bairro de baixa renda de Londrina - PR. UNOPAR Científica Ciências Biológicas e da Saúde, 4, 55-60.

Ogliari, T. C. C.; Passos, J. T. (2002), Enteroparasitas em estudantes de quintas séries do Colégio Estadual de Terra Boa, Campina Grande do Sul, Paraná (Sul do Brasil). Acta Biol. Paranaense, 31, 65-70.
Pedroso, R. S.; Siqueira, R. V. (1997), Pesquisa de cistos de protozoários, larvas e ovos de helmintos em chupetas. J. Pediatr., 73, 21-25.

Porcu, M. L.; Watanabe, N. (1998), Estudo da prevalência de enteroparasitoses no município de Maringá. Abstract presented at $6^{\text {th }}$ Reunião Especial da SBPC, October, Maringá, Paraná. Annals...p. 446.

Pupulin, A. R. T.; Gomes, M. L.; Dias, M. L. G. G.; Araújo, S. M.; Guilherme, A. L. F.; Kuhl, J. B. (2004), Giardíase em creches do município de Maringá, PR. Rev. Bras. Anal. Clín., 36, 147-149.

Rocha, R. S.; Silva, J. G.; Peixoto, S. V.; Caldeira, R. L.; Firmo, J. O. A.; Carvalho, O. S.; Katz N. (2000), Avaliação da esquistossomose e de outras parasitoses intestinais, em escolares do município de Bambuí, Minas Gerais, Brasil. Rev. Soc. Bras. Med. Trop., 33, 431-436.

Secretaria Estadual de Desenvolvimento Urbano do Estado do Paraná - SEDU/PR. http://www.paranacidade.org.br/municipios/municipi o.php. Accessed on 1 June 2005.

Tashima, N. T.; Simões, M. J. S. (2004), Enteroparasitic occurrence in fecal samples analyzed at the University of western São Paulo-UNOESTE clinical laboratory, Presidente Prudente, São Paulo State, Brazil. Rev. Inst. Med. Trop. São Paulo, 46, 243-248.

Tavares-Dias, M.; Grandini, A. G. (1999), Prevalência e aspectos epidemiológicos de enteroparasitoses na população de São José da Bela Vista, São Paulo. Rev. Soc. Bras. Med. Trop., 32, 63-65.

UNICEF (Fundo das Nações Unidas para a Infância). (1995), Situação Mundial da Infância. Unicef, Brasília.

Received: January 30, 2006; Revised: March 29, 2007; Accepted: May 05, 2008. 